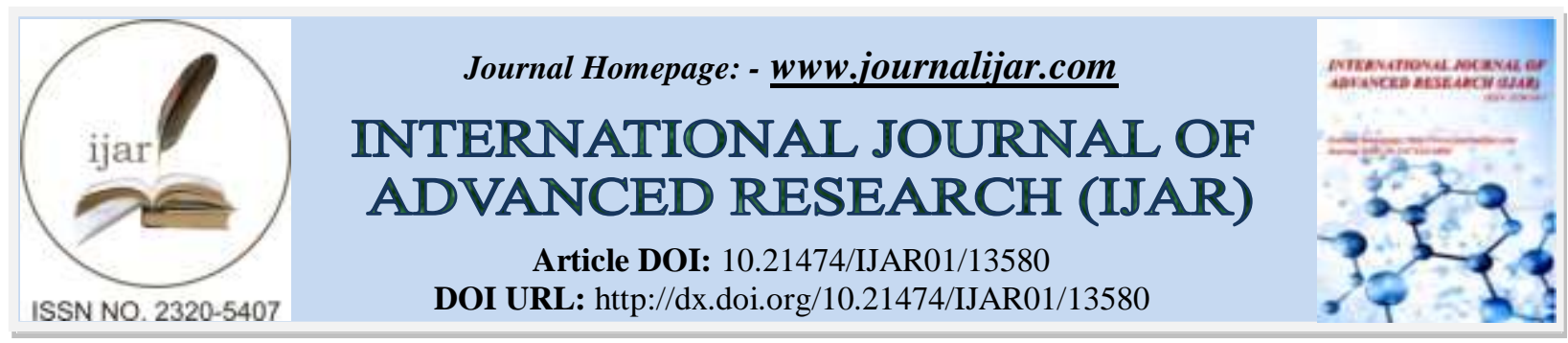

RESEARCH ARTICLE

\title{
A STUDY ON ONLINE CONSUMER BUYING BEHAVIOR DURING FESTIVAL SEASONS IN COIMBATORE CITY
}

\author{
Dr. S. Mahendran ${ }^{1}$ and Mrs. K. Malathi ${ }^{2}$ \\ 1. Principal and Guide, Department of Commerce, Pioneer College of Arts and Science, Coimbatore, India. \\ 2. Ph.D. Research Scholar, Department of Commerce, Pioneer College of Arts and Science, Coimbatore, India.
}

\section{Manuscript Info}

..........................

Manuscript History

Received: 24 August 2021

Final Accepted: 27 September 2021

Published: October 2021

Key words:-

Consumer Behaviour, Digitalisation,

Consumer Perception, E-Commerce

\section{Abstract}

Due to rapid development in technology, nowadays consumers use the Internet in many ways to take day-to-day decisions. For example, consumers are eager to seek reviews of others who purchased the goods earlier through various e-commerce sites while they purchase goods online. These days everything is available online and consumers are realising the importance of digitalisation and started purchasing through various online sites. The major shopping festivals in Tamilnadu are Pongal, Aadi Perukku, Onam, Ramzan, Bakrid, Diwali, Christmas, National festivals like Independence Day, Gandhi Jayanthi, Republic Day, and many more. During the Festival time, sales are the latest trend in contributing to the growth of online sales. All online marketing sites use festival time to promote their products and provide various attractive offers in order to push up their sales. This study is an attempt to understand the various factors that contribute highly towards festival spends which determine the purchase behaviour of consumers.

Copy Right, IJAR, 2021,. All rights reserved.

\section{Introduction:-}

Festivals are always connected with joy, sharing, and celebration. Due to digitalization, everything is available online from durable items to non-durable items. These days Consumers are realising the importance of digitization and seeking more personalized dominion. Most of the consumers in urban areas are using online sites for their purchases but now, the trend is slowly increasing in villages as well. Increased earnings in the hands of consumers, growth in the economy, increased availability of goods and services, and availability of credit services may lead to new segmentation in consumer markets. Whether it is Android phones, credit cards, and all other gadgets, people clearly seem to be spending more, particularly on discretionary goods. The credit facility from banks and private money lenders has been increasing at a rapid rate. This shows the stiff competition in the competitive consumer market.

Festival Sales are the recent trend in contributing to the development of online sales. Maximum of the online marketers use the festival time to promote their goods and services at moderate discounts or other offers viz., discount coupons, cash backs, buy two and get 2, and more offers. The major shopping festival in Tamilnadu are Pongal, Aadi Perukku, Onam, Ramzan, Bakrid, Diwali, Christmas, National festivals like Independence Day, Gandhi Jayanthi, Republic Day, and many more., During these festival periods, most of the online sites provide many attractive offers by creating special names for such shopping events. Some examples of such shopping events are - Flipkart Diwali sale, Budget Dhamaka, Flipkart Fashion Days, Flipkart super saver days, Amazon's Great 
Freedom Festival, Meesho's The Maha Indian Festivals offer. This study is entitled to understand consumer buying behaviour in India during the festival season.

\section{Significanece of the Study:-}

1. The significance of the study is to know whether the customers buying behaviour towards online Shopping sites.

2. The study is to analyze about the perception of customers about Shopping during festival season in various online shopping sites.

\section{Consumer Buying Behaviour:}

According to Boone and Kurtz, "consumer behaviour is the outcome of both individual and environmental influences". To be specific, consumer behaviour refers to the act of consuming a good or service. Consumer behaviour helps us to understand why and why not an individual purchases goods and services from the market. The study of consumer behaviour explains us to:

Why a consumer does purchase a product?

Why don't consumers purchase a product?

On which occasion does a consumer purchase a product?

On which mode does a consumer purchase a product?

Consumer Behaviour is a branch which deals with the various stages of purchasing products or services by the consumers goes through before his end-use.

Why do consumer buys a product?

1. Requirement

2. Prestige

3. Gifting

Why not consumers do buy a product?

1. No necessity

2. Lack of Funds

3. Taste

On which occasion do you think consumers to purchase products?

1. Festive season

2. Birthday

3. Anniversary

4. Marriage or other special occasions.

There are several factors that influence buying decision of a consumer ranging from psychological, social, and economic, and so on.

\section{Objectives of the Study:-}

The study is being carried out to understand the following objective as part of the survey:

1. Various Factors contribute highly towards festival spends which determine the purchase behaviour of consumers.

2. To know the number of people who shop online

3. To know about the satisfaction of customers towards online shopping.

4. To analyse the attitude of customers towards the recent trends in online shopping

5. To know the reasons for preferring online shopping

6. To analyse the convenience of shopping through online and offline

7. To analyse the attitude of customers towards online shopping during the non-festival season 


\section{Review of Literature:-}

1. T.Sreerekha, S.Praveen Kumar (2018) "Consumer Preference Towards Branded Apparel Purchase In Coimbatore City” (IJSDR) International Journal of Scientific Development and Research, march 2018 IJSDR, volume 3, Issue 3, ISSN:2455-2631.

2. Prof.Lakshminarayana.K, Dr.Sreenivas DL (2018) “A Study of Consumer Buying Behaviour towards Branded Apparels in Selected cities of Karnataka" International Journal of Advanced in Management, Technology and Engineering Sciences, volume 8, issue 3, March 2018, ISSN NO: 2249-7455.

3. VT.Shailashri,Dr. P.S.Aithal,Dr.SurekhaShenoy(201 8)“A Study on Online Consumer Buying Behaviour during Festive seasons in India" Advance in Information Technology, Management, Social Sciences, and Education, December 2018, ISBN No:978-81-938040-8-7.

4. Kathiresan Dr.Radha , "Marketing" Consumer Behaviour page number 188, Prasanna Publishers, Chennai - 5, Edition: 2004.

\section{Limitations of the Study:}

1. This study is concentrated only on online consumers.

2. Consumers who purchase products at the shopping malls are eliminated.

3. Shopping during the non-festival season is not taken into account.

4. Data collected from the customers may have bias

5. Only 100 respondents are taken into study.

\section{Suggestion:-}

1. Marketers will need to take a holistic approach in preparing marketing campaigns for their products to be promoted during a festival sale on the different e-commerce sites.

2. Flipkart, Meesho and Amazon are the best online sites for deriving profits.

3. No separate marketing strategy is required to target gender.

4. The technique of tying up with Banks and offering discounts on the cards works well as seen from the analysis.

5. Festival sales campaigns and products can be targeted more on Women as they are very impulsive in their buying behaviour and do not wait for a festival sale.

\section{Conclusion:-}

Festival season plays an important role in the Indian scenario. There are a lot of emotions attached to different festivals in India. Their purchasing behaviour mostly judges on the basis of these festivals. Marketers will need to take an integrated approach in preparing marketing campaigns for their products to be promoted during a festival sale on the different e-commerce sites. 60 respondents prefer online shopping during the festival season. Hence festival sales are indeed very beneficial for marketers. Flipkart, Amazon, Meesho, Snapdeal and Shopclues are their best bets in deriving profits. No separate marketing strategy is required to target men and women separately as the proportions of the gender shopping during the festival sale as like. The technique of tying up with Banks and offering discounts on the cards works well as seen from the analysis. The promotional efforts that can be maintained must be distributed evenly throughout the festival as it does not make any difference. If, the efforts are concentrated on the first day or the last day since from my analysis I saw that the day and expenditure are not related. During this Festival sales campaign, a maximum of the products can be targeted more on women as they are much impulsive in their purchase behaviour and they do not wait for festive sales. The conclusion is that further importance has to be given towards improvement of quality of service during festival season sales. 